\title{
Frailty and mortality in long-term care facilities for older people in Brazil: a survival analysis
}

\section{Fragilidade e mortalidade em instituições de longa permanência para idosos no Brasil: estudo de sobrevivência}

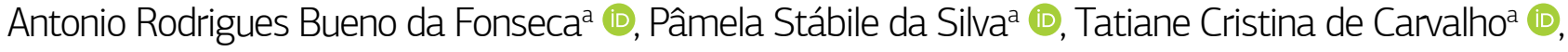

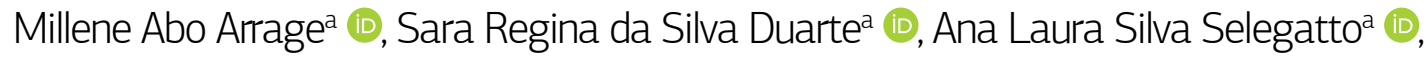 \\ Adriana Polachini do Valle ${ }^{a}$ (1), Paulo José Fortes Villas Boas ${ }^{a}$ (1)
}

OBJECTIVES: To investigate the effect of frailty on 1-year mortality in long term-care facility (LTCF) residents. METHODS: This was a prospective cohort study with survival analysis of 209 participants living in 15 Brazilian LTCFs. Data on chronic diseases, age, sex, medication use, dependence in activities of daily living (ADLs; Katz index), and frailty (FRAIL scale) were collected at baseline, and death after 1 year was the outcome measure. Kaplan-Meier estimate and log-rank test were used to analyze the survival of residents. RESULTS: In the initial assessment, 65.07 of the residents were women, and the median age was 82 (interquartile range, $71-88$ ) years, with 55\% being over 80 years old. Overall, $88 \%$ had 2 or more diseases, $59.81 \%$ were using 5 or more medications, $42.11 \%$ were considered frail, 34.92\% pre-frail, and 22.97\% robust, and 69.94\% were dependent in 3 or more ADLs. During the 12-month follow-up, $19.61 \%$ of the residents $(n=41)$ died. In the survival analysis for death, there was a statistically significant association with frailty $(p=0.03)$ and dependence in ADLs ( $p=0.04)$. CONCLUSIONS: In this population of LTCF residents, frailty and functional dependence were associated with death.

KEYWORDS: frailty; long-term care; mortality; aged.

OBJETIVOS: Investigar o efeito da fragilidade na mortalidade em 1 ano em residentes de instituições de longa permanência para idosos (ILPIs). METODOLOGIA: Estudo de coorte prospectivo com análise de sobrevivência de 209 participantes residentes em 15 ILPIs brasileiras. Dados sobre doenças crônicas, idade, sexo, uso de medicamentos, dependência nas atividades da vida diária (AVDs; índice de Katz) e fragilidade (escala FRAIL) foram coletados no início do estudo, e morte após 1 ano foi a medida de desfecho. A estimativa de Kaplan-Meier e o teste de log-rank foram usados para analisar a sobrevida dos residentes.. RESULTADOS: Na avaliação inicial, 65,07\% dos residentes eram mulheres e a mediana da idade era de 82 (intervalo interquartil, 71-88) anos, 55\% com mais de 80 anos. Em geral, 88\% tinham 2 ou mais doenças, 59,81\% usavam 5 ou mais medicamentos, $42,11 \%$ foram considerados frágeis, 34,92\% pré-frágeis e 22,97\% robustos e 69,91\% eram dependentes em 3 ou mais AVDs. No decorrer do seguimento de 12 meses, $19,61 \%$ dos residentes $(n=41)$ evoluíram para óbito. Na análise de sobrevivência para evento morte, houve associação estatisticamente significativa com fragilidade $(p=0,03)$ e dependência para AVDs ( $p=0,04)$. CONCLUSÕES: Nesta população de residentes de ILPIs, fragilidade e dependência funcional estiveram associadas ao óbito. PALAVRAS-CHAVE: fragilidade; cuidados de longa duração; mortalidade; idosos.

aBotucatu Medical School, Universidade Estadual Paulista São Paulo - Botucatu (SP), Brazil.

Correspondence data

Paulo José Fortes Villas Boas - Rua General Telles, 1.519 - CEP 18602-120 - Botucatu (SP), Brazil. E-mail: paulo.boas@unesp.br Received on: 10/02/2021. Accepted on: 10/25/2021

How to cite this article: Fonseca ARB, Silva PS, Carvalho TC, Arrage MA, Duarte SRS, Selegatto ALS, Valle AP, Villas Bias PJF. Frailty and mortality in long-term care facilities for older people in Brazil: a survival analysis. Geriatr Gerontol Aging. 2021;15:e0210057. https://doi.org/10.53886/gga.e0210057 https://doi.org/10.53886/gga.e0210057 


\section{INTRODUCTION}

Prospective observational studies investigating adverse outcomes in older people living in long-term care facilities (LTCFs) in Brazil are scarce. ${ }^{1}$ Studies have shown that frailty is associated with hospitalization and mortality in this setting. ${ }^{2-4}$

LTCF residents are becoming increasingly older and frailer and developing multiple diseases, with more complex health needs upon admission to the LTCF. ${ }^{5}$ Barros et al. showed that, among 209 LTCF residents, the mean age was 81 years and $42 \%$ of them were frail. ${ }^{6}$ Incorporating frailty assessment into LTCFs can assist in the early identification of residents who are at increased risk of mortality, hospitalization, and other adverse health outcomes and may contribute to proper care planning and management. ${ }^{7}$

The present study aimed to evaluate the prevalence of frailty according to the FRAIL scale and its association with mortality after 12 months.

\section{METHODS}

This was a prospective cohort study with survival analysis of 209 older people living in 15 Brazilian LTCFs.

In the initial assessment, data were collected on chronic diseases, age, sex, medication use, dependence in activities of daily living (ADLs; Katz index) ${ }^{8}$, and frailty (FRAIL scale) . $^{9}$ The FRAIL scale assesses 5 self-reported components: fatigue, resistance, ambulation, illness, and loss of weight, with scores ranging from 0 to $5(0=$ best to $5=$ worst $)$. The person is frail when 3 or more components are present. ${ }^{10}$

Deaths were recorded over a 12 -month period starting at the initial assessment.

Descriptive analysis was performed with data obtained in the initial assessment.

We evaluated the accuracy of the frailty index to independently predict 12 -month mortality using cumulative Kaplan-Meier survival curves and the log-rank test for 2 categories (frail and non-frail). Kaplan-Meier curves were used to analyze the survival of residents.

The study protocol was approved by the Research Ethics Committee of the Botucatu Medical School-Unesp (approval number 4640 571).

\section{RESULTS}

In the initial assessment, $65.07 \%$ of the residents were women and the median age was 82 (interquartile range [IQR], $71-88$ ) years, with $55 \%$ being over 80 years old. Overall, $88 \%$ had 2 or more diseases, $59.81 \%$ were using 5 or more medications, $49.32 \%$ had heart disease, $39.71 \%$ had dementia, $22.51 \%$ had diabetes, and $14.42 \%$ had cancer; $42.11 \%$ were considered frail, $34.92 \%$ pre-frail, and $22.97 \%$ robust and $69.94 \%$ were dependent in 3 or more ADLs.

During the 12-month follow-up, $19.61 \%$ of the residents $(n=41)$ died, with a median of 153 (IQR, 79-253) days to the event.

In the survival analysis for death, there was a statistically significant association with frailty $(p=0.03 ; \log -$ rank $=4.42)$ (Figure 1 ) and dependence in ADLs $(p=0.04 ; \log$-rank $=4.18)$.

\section{DISCUSSION}

The main findings of this study were that the risk of death was higher in frail than in non-frail LTCF residents and among those dependent in ADLs. Regardless of the level of frailty, more than half of the residents survived through the 12-month follow-up as observed in previous studies. ${ }^{1,2}$

Frailty is common in LTCFs and significantly affects the health status of residents, thus impacting families and society. ${ }^{11}$ In frailty studies, mortality assessment is a common outcome measure, as it is a relevant, non-arbitrary, dichotomous event of importance in epidemiological studies., ${ }^{2,3,12}$

Several tools, such as the FRAIL-NH to evaluate frailty in nursing homes ${ }^{1}$ and the Frailty Index,${ }^{13}$ have been previously used to identify frail LTCF residents at increased risk of adverse health events. The FRAIL scale, used in this study, has most of the items routinely used in the assessment of frailty in LTCFs, provides a simple and practical

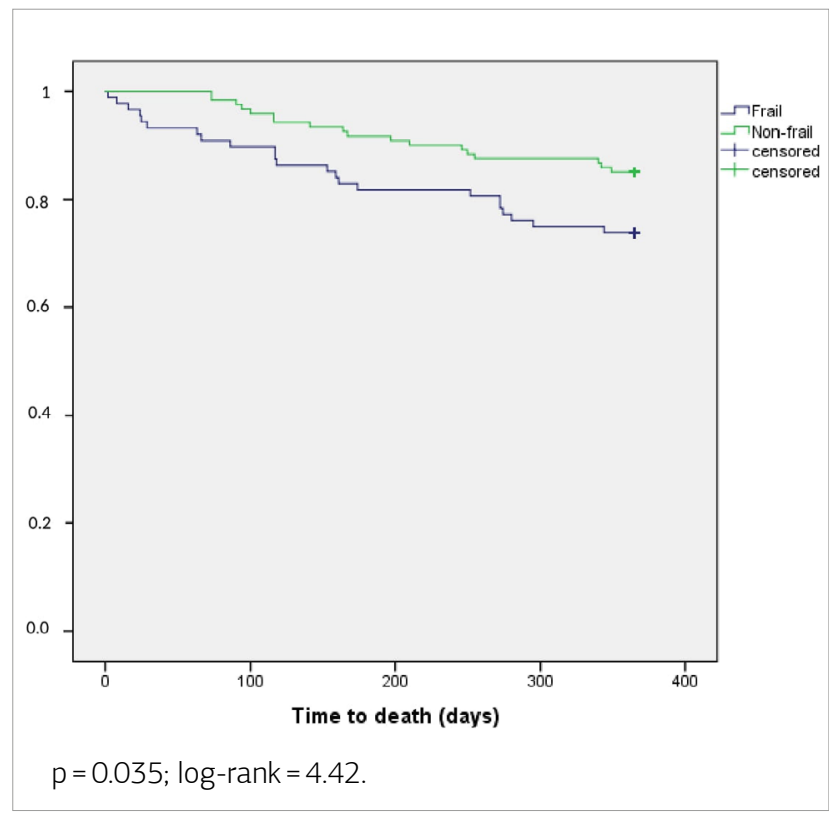

Figure 1. Kaplan-Meier curves for time to death stratified by frailty level. 
method for screening residents for frailty in this scenario and can be used to identify residents who require more comprehensive care planning and management, being validated in this setting. ${ }^{14}$

The strength of this study lies in the number of residents from different LTCFs in the same location and in the use of an easy-to-administer instrument. Some limitations of the present study should be noted, such as the lack of analysis of associations with other conditions observed. This aspect will be analyzed in a future study, as well as other outcomes such as hospitalization and visits to the emergency department.

\section{CONCLUSIONS}

In this population of LTCF residents, frailty and functional dependence were associated with death.

\section{ACKNOWLEDGMENTS}

Our special recognition and thanks to all long-term care facilities that contributed to this study by sharing information.

\section{CONFLICTS OF INTEREST}

The authors declare no conflicts of interest.

\section{FUNDING}

This work was supported by the Pró-Reitoria de Pesquisa da Universidade Estadual Paulista de São Paulo - UNESP PIBIC proc. 1078/2020.

\section{AUTHORS' CONTRIBUTION}

ARBF: conceptualization, data curation, formal analysis, investigation, methodology, project administration, validation, writing - original draft, writing - review \& editing. PSS: writing - review \& editing. TCC: conceptualization, writing - review \& editing. MAA: writing - review \& editing. SRSD: writing - review \& editing. ALSS: writing - review \& editing. APV: data curation, formal analysis, validation, writing - review \& editing. PJVB: conceptualization, data curation, formal analysis, validation, investigation, methodology, project administration, writing - original draft, writing - review \& editing.

\section{REFERENCES}

1. Romanini CV, Vilas Boas P, Cecato JF, Robello E, Borges MK, Martinelli JE. Prediction of death with the FRAIL-NH in institutionalized older adults: a longitudinal study from a middle-income country. J Nutr Health Aging. 2020;24(8):817-20. https://doi.org/10.1007/s12603-020-1464-7.

2. Theou O, Sluggett JK, Bell JS, Lalic S, Cooper T, Robson L, et al. Frailty, hospitalization, and mortality in residential aged care. J Gerontol A Biol Sci Med Sci. 2018;73(8):1090-6. https://doi.org/10.1093/ gerona/glx185.

3. Tabue-Teguo M, Kelaiditi E, Demougeot L, Dartigues JF, Vellas B, Cesari M. Frailty index and mortality in nursing home residents in France: results from the INCUR study. J Am Med Dir Assoc. 2015;16(7):603-6. https://doi.org/10.1016/j.jamda.2015.02.002.

4. Luo H, Lum TYS, Wong GHY, Kwan JSK, Tang JYM, Chi I. Predicting adverse health outcomes in nursing homes: a 9-year longitudinal study and development of the FRAlL-Minimum Data Set (MDS) quick screening tool. J Am Med Dir Assoc. 2015;16(12):1042-7. https://doi.org/10.1016/j.jamda.2015.09.006.

5. Sluggett JK, Ilomäki J, Seaman KL, Corlis M, Bell JS. Medication management policy, practice and research in Australian residential aged care: current and future directions. Pharmacol Res. 2017;116:20-8. https://doi.org/10.1016/j.phrs.2016.12.011.

6. Barros ENC, Valle AP, Braga PE, Viscondi JYK, Fonseca ARB, Vanni T, et al. COVID-19 in long-term care facilities in Brazil: serological survey in a post-outbreak setting. Rev Inst Med Trop São Paulo. 2021;29:63:e10. https://doi.org/10.1590/S1678-9946202163010.

7. Nazir A, Unroe K, Tegeler M, Khan B, Azar J, Boustani M. Systematic review of interdisciplinary interventions in nursing homes. J Am Med Dir Assoc. 2013;14(7):471-8. https://doi.org/10.1016/j. jamda.2013.02.005.
8. Lino VTS, Pereira SRM, Camacho LAB, Ribeiro Filho ST, Buksman S. Adaptação transcultural da Escala de Independência em Atividades da Vida Diária (Escala de Katz). Cad Saúde Pública 2008;24(1):10312. https://doi.org/10.1590/s0102-311×2008000100010.

9. Aprahamian I, Cezar NOC, Izbicki R, Lin SM, Paulo DLV, Fattori A, et al. Screening for Frailty With the FRAIL Scale: A Comparison With the Phenotype Criteria. J Am Med Dir Assoc 2017;18(7):592-6. https://doi.org/10.1016/j.jamda.2017.01.009

10. Morley JE, Malmstrom TK, Miller DK. A simple frailty questionnaire (FRAIL) predicts outcomes in middle aged African Americans. J Nutr Health Aging 2012;16(7):601-8. https://doi.org/10.1007/s12603012-0084-2

11. De Silva TR, Theou O, Vellas B, Cesari M, Visvanathan R. Frailty screening (frail-nh) and mortality in french nursing homes: results from the incidence of pneumonia and related consequences in nursing home residents study. J Am Med Dir Assoc. 2018;19(5):411-4. https://doi.org/10.1016/j.jamda.2017.12.101.

12. Hogan DB, Freiheit EA, Strain LA, Patten SB, Schmaltz HN, Rolfson D, et al. Comparing frailty measures in their ability to predict adverse outcome among older residents of assisted living. BMC Geriatr 2012;12:56. https://doi.org/10.1186/1471-2318-12-56.

13. Theou O, Brothers TD, Mitnitski A, Rockwood K. Operationalization of frailty using eight commonly used scales and comparison of their ability to predict all-cause mortality. J Am Geriatr Soc 2013;61(9):1537-51. https://doi.org/10.1111/jgs.12420.

14. Dent E, Martin FC, Bergman H, Woo J, Romero-Ortuno R, Walston JD. Management of frailty: opportunities, challenges, and future directions. Lancet. 2019;394(10206):1376-86. https://doi.org/10.1016/S01406736(19)31785-4. 